\title{
Effects of nitrogen fertilization on growth and yield of diterpene glycosides in stevia (Stevia rebaudiana Bertoni)
}

\section{Efectos de la fertilización de nitrógeno en el desarrollo y producción de glucósidos diterpénicos en estevia (Stevia rebaudiana Bertoni)}

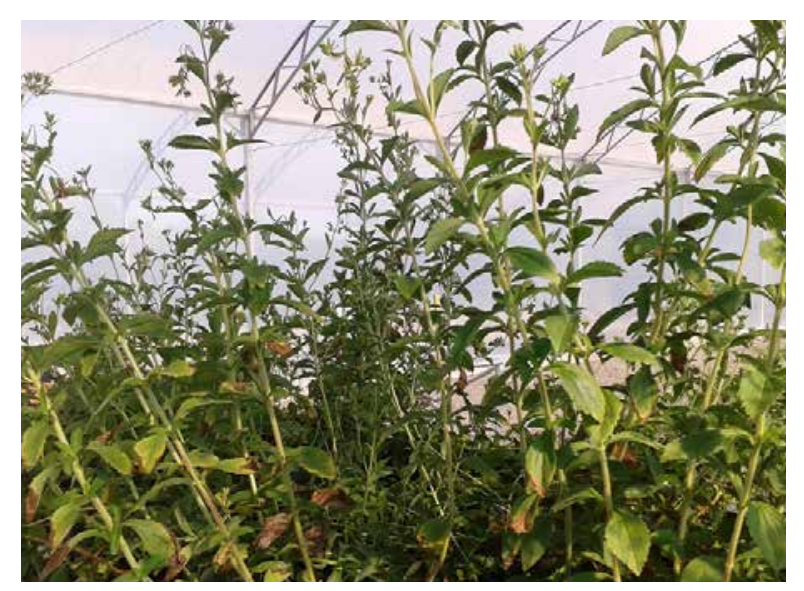

RÔMULO JOÃO DEBARBA ${ }^{1,5}$

CÍCERO DESCHAMPS ${ }^{2}$

LUIZ ALBERTO KANIS ${ }^{3}$

DIEGO MOTERLE 3

MARCIO RAMPELOTTI ${ }^{4}$

Matrices of Stevia rebaudiana.

Photo: R.J. Debarba

\section{ABSTRACT}

The effects of different nitrogen doses on dry weight yield, stevioside and rebaudioside A contents, and yields were evaluated in stevia (Stevia rebaudiana Bertoni). This study was carried out at the Instituto Federal Catarinense, Rio do Sul (SC), Brazil, under decreasing photoperiods. A randomized complete block design with four blocks and five treatments $\left(0,65,135,200\right.$ and $\left.270 \mathrm{~kg} \mathrm{ha}^{-1} \mathrm{~N}\right)$ was used. Variables related to dry weight yield (total dry weight, leaf dry weight, stem dry weight, number of secondary branches and tertiary branches, and main stem length), growth rates (total leaf area, leaf area index, specific leaf area, leaf area ratio, leaf weight ratio), and stevioside and rebaudioside A contents and yields were evaluated. The doses of nitrogen fertilization did not affect the variables related to dry weight yield, stevioside and rebaudioside A contents and yields, or rebaudioside A:stevioside ratio in stevia genotype 8 (G8), grown under decreasing photoperiods.

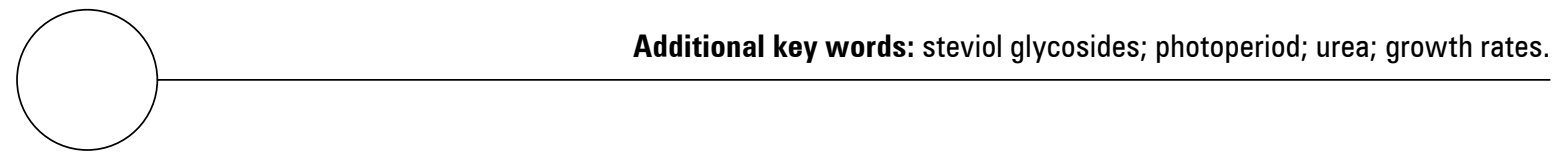

\footnotetext{
1 Instituto Federal Catarinense, campus Rio do Sul, Rio do Sul (Brazil). ORCID Debarba, R.J.: 0000-0002-0074-8866

2 Universidade Federal do Paraná, Departamento de Fitotecnia e Fitossanitarismo, Curitiba (Brazil). ORCID Deschamps, C.: 0000-0003-0786-0532

3 Universidade do Sul de Santa Catarina, Grupo de Pesquisa em Tecnologia Farmacêutica, Tubarao (Brazil). ORCID Kanis, L.A.: 0000-0001-7600-7530; ORCID Moterle, D.: 0000-0002-9383-4295

4 Instituto Federal Catarinense, campus Rio do Sul, Rio do Sul (Brazil). ORCID Rampelotti, M.: 0000-0002-9533-0971

5 Corresponding author. romulo.debarba@ifc.edu.br
} 


\section{RESUMEN}

El efecto de diferentes tasas de nitrógeno en la producción de biomasa, el contenido y rendimiento de esteviósido y rebaudiósido A en el cultivo de estevia se evaluaron en un experimento de campo en el Instituto Federal Catarinense, Rio do Sul (SC), Brasil, en condiciones de fotoperíodo decreciente. Se utilizó un diseño de bloques completos al azar con cuatro bloques y cinco tratamientos $\left(0,65,135,200\right.$ y $\left.270 \mathrm{~kg} \mathrm{ha}^{-1} \mathrm{~N}\right)$. Se evaluaron las variables relacionadas con la producción de biomasa (DM total, tallo MS, hojas MS, número de ramas secundarias, número de ramas terciarias y longitud de rama más grande), variables relacionadas con los índices de crecimiento (AFT, IAF, AFE, RAF y RPF) y también variables relacionadas con el contenido y el rendimiento de esteviósido y rebaudiósido A. Las diferentes dosis de fertilización nitrogenada no afectaron las variables relacionadas con la acumulación de materia seca en el genotipo G8 cultivado en condiciones de fotoperíodo decreciente en las condiciones de campo. Los niveles de fertilización nitrogenada no afectaron los niveles de esteviósido y rebaudiósido A, la productividad de esteviósido y rebaudiósido A y la proporción de rebaudiósido A / esteviósido en el G8 cultivado en condiciones de fotoperíodo de disminución de campo.

Palabras clave adicionales: glucósidos de esteviol; fotoperiodo; urea; tasa de crecimiento.

Received: 05-02-2020 Accepted: 22-12-2020 Published: 17-01-2021

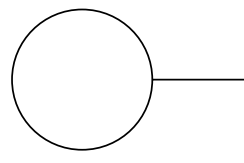

INTRODUCTION

The cultivation of stevia (Stevia rebaudiana Bertoni) in Brazil is somewhat limited, and there needs to be more research on management practices to meet the needs of the domestic and foreign markets and to compete with other production centers. Stevia belongs to the Asteraceae family. It synthesizes two glycosides (stevioside and rebaudioside A) of great commercial and nutraceutical value in its secondary metabolic pathways. These values are mainly due to the high sweetening value, with a glycemic index of zero (Espita et al., 2009; Yadav et al., 2012).

Nitrogen $(\mathrm{N})$ plays an important role in crop metabolism and nutrition. Nitrogen deficiency causes disorders in the synthesis of several organelles and enzymes responsible for the growth and accumulation of secondary metabolites (Gobbo-Neto and Lopes, 2007). Nitrogen is key in regulating photosynthesis, with great importance in the constitution of ribulose-1,5-bisphosphate carboxylase/oxygenase (Rubisco) and other enzymes involved in the photosynthetic process (Tavarini et al., 2015). Excess $\mathrm{N}$ causes problems in oil accumulation in sunflowers, as well as biomass accumulation in plants due to potassium dilution (Cantarella, 2007). The increased incidence of pests and diseases is also observed when nitrogen is offered to crops at excessive doses. Leaf thickness is an important characteristic for determining photosynthetic capacity and is directly affected by excess or lacking nitrogen (Tavarini et al., 2015).
A small number of studies have correlated the effect of nitrogen fertilization (Aladakatti et al., 2012; Tavarini et al., 2015) to dry weight yield and secondary metabolites in stevia. Thus, the assessment of different doses of nitrogen fertilization is important for the efficient cultivation of Stevia rebaudiana Bert. in the Alto Vale do Itajaí region.

This study aimed to evaluate the response of stevia to nitrogen fertilization in the soil and climate conditions of the Alto Vale do Itajaí region.

\section{MATERIALS AND METHODS}

The study was conducted in 2015/2016 in the experimental area of the IFC - Campus Rio do Sul (SC), Brazil. The geographical coordinates of this location are $27^{\circ} 21^{\prime} 45^{\prime \prime} \mathrm{S}$ and $49^{\circ} 64^{\prime} 35^{\prime \prime} \mathrm{W}$. The altitude of the study site is $693.7 \mathrm{~m}$. The local climate is Cfa according to Köppen classification. The weather data during the experiment period are shown in table 1.

The soil of the experimental area used for the installation of the experiment is classified as a Cambissolo Háplico Aluminico típico (Embrapa, 2018). The soil analysis data are shown in table 2.

The soil was corrected according to the Fertilization and Liming Manual for the States of Santa Catarina 
Table 1. Rainfall, temperature, humidity and photoperiod during the experiment period. Rio do Sul, Brazil, 2015/2016.

\begin{tabular}{|l|c|c|c|c|}
\hline Weather data & December & January & February & March \\
\hline Rainfall $(\mathrm{mm})$ & 152 & 81.0 & 184.2 & 268.2 \\
\hline Maximum temperature $\left({ }^{\circ} \mathrm{C}\right)$ & 32.7 & 33.4 & 35.6 & 29.9 \\
\hline Minimum temperature $\left({ }^{\circ} \mathrm{C}\right)$ & 14.4 & 14.4 & 15.1 & 11.7 \\
\hline Average temperature $\left({ }^{\circ} \mathrm{C}\right)$ & 21.7 & 21.9 & 22.6 & 20.3 \\
\hline Relative air humidity $(\%)$ & 89 & 91 & 93 & 94 \\
\hline Photoperiod $(\mathrm{h})$ & 13.72 & 13.68 & 13.24 & 12.57 \\
\hline
\end{tabular}

Source: IFC - Rio do Sul, weather station, 2016.

Table 2. Chemical characteristics of the soil used in the experiment.

\begin{tabular}{|c|c|c|c|c|c|c|c|c|c|}
\hline \multirow{2}{*}{$\begin{array}{c}\mathrm{pH} \\
\text { SMP }\end{array}$} & $\mathrm{Al}^{+3}$ & $\mathrm{H}^{+}+\mathrm{Al}^{3+}$ & $\mathrm{Ca}^{2+} \mathrm{C}$ & $\mathrm{Mg}^{2+}$ & CEC & $\mathrm{K}^{+}$ & $P$ & \multirow{2}{*}{$\begin{array}{c}\mathrm{OM} \\
\%\end{array}$} & \multirow{2}{*}{$\begin{array}{l}V \\
\%\end{array}$} \\
\hline & \multicolumn{5}{|c|}{ cmolc $\mathrm{dm}^{-3}$} & \multicolumn{2}{|c|}{$\mathrm{mg} \mathrm{dm}^{-3}$} & & \\
\hline 5.2 & 2.3 & 10.9 & 2.4 & 1.4 & 14.88 & 72.0 & 1.4 & 2.3 & 26.78 \\
\hline
\end{tabular}

and Rio Grande do Sul (SBCS, 2016). Fertilization was carried out with $8.3 \mathrm{t} \mathrm{ha}^{-1}$ limestone, $130 \mathrm{~kg} \mathrm{ha}^{-1}$ $\mathrm{P}_{2} \mathrm{O}_{5}$ and $40 \mathrm{~kg} \mathrm{ha}^{-1} \mathrm{~K}_{2} \mathrm{O}$, supplied by dolomitic limestone simple superphosphate and potassium chloride, respectively. Limestone was applied two months prior to the experiment, and the other correctives were applied when preparing the beds.

Stevia (Stevia rebaudiana Bert.) genotype 8 (G8), provided by the Empresa Brasileira de Pesquisa Agropecuária, Centro Nacional de Recursos Genéticos (Embrapa - Cenargen), was used in this study because it has a higher rebaudioside A yield than other genotypes (Francisco, 2015).

The seedlings were obtained from branches of mother plants grown at Fazenda Canguiri, which is part of the Universidade Federal do Paraná, located in Pinhais (PR), Brazil. The methodology was described by Carvalho and Zaidan (1995) and Espita et al. (2009), with the use of rooting inducers, indole-3-butyric acid (IBA), at a concentration of $2,000 \mathrm{mg} \mathrm{L}^{-1}$. The seedlings were produced in tubes on the premises of the Instituto Federal Catarinense, campus Rio do Sul (SC), using Macrofértil ${ }^{\circledR}$ commercial substrate. At transplant, the seedlings were subjected to apical bud break, as recommended by Lima Filho et al. (2004).

The seedlings were transplanted on December 15, 2015 in beds prepared with a raised bed planter. The spacing was $0.25 \times 0.50-80.000$ plants/ha.
A randomized complete block design with five treatments and four replicates was used. The treatments consisted of five nitrogen doses provided by urea (45\% N): $0 \%, 75 \%$ (65 $\mathrm{kg} \mathrm{ha}^{-1} ; 0.85 \mathrm{~g} /$ plant), $150 \%$ (135 kg ha-1; $1.65 \mathrm{~g} /$ plant), 225\% (200 kg ha ${ }^{-1} ; 2.53$ $\mathrm{g} /$ plant $)$ and $300 \%$ (270 $\mathrm{kg} \mathrm{ha}^{-1} ; 3.38 \mathrm{~g} / \mathrm{plant}$ ). These doses were defined based on the recommendation of nitrogen fertilization for the soil of the experimental area $\left(90 \mathrm{~kg} \mathrm{ha}^{-1}\right)$ (SBCS, 2016). The application of urea was split into three equal doses (at transplanting of the seedlings, 30 and $45 \mathrm{~d}$ after transplanting). The splitting of nitrogen fertilization in three differs from the recommendation of the SBCS (2016). However, this was necessary to more accurately evaluate the effects of the fertilizer doses used in our study.

Each plot had 21 plants (3 rows of 7 plants), with 5 plants per useful area. The harvest, which occurs with 5\% flowering (Lima Filho et al., 2004), was different for each treatment. It was on average $86 \mathrm{~d}$ after transplant. The following characteristics were evaluated: Stem dry weight (SDW), leaf dry weight (LDW), total dry weight (TDW), main stem length, number of secondary and tertiary branches, total leaf area (TLA), leaf area index (LAI), specific leaf area (SLA), leaf area ratio (LAR), leaf weight ratio (LWR), stevioside and rebaudioside A yield per plant and ha, stevioside and rebaudioside A content, and rebaudioside A:stevioside ratio.

The plants of the useful plot were cut $5 \mathrm{~cm}$ from the soil (Lima Filho et al., 2004) and taken to the Botany 
Laboratory of the Instituto Federal Catarinense, Campus Rio do Sul (SC), to separate the leaves from the branches. The dry weight of the leaves and branches was determined on a digital scale after drying the plants at $50^{\circ} \mathrm{C}$ until constant weight (Espita et al., 2009). The height of the largest stem was measured with a tape measure, while the number of secondary and tertiary branches was counted.

The total leaf area (TLA), leaf area index (LAI), specific leaf area (SLA), leaf area ratio (LAR) and leaf weight ratio (LWR) were obtained using the methodologies described by Jarma et al. (2006) and Cunha et al. (2010).

To determine stevioside and rebaudioside A yield, $1 \mathrm{~g}$ samples of leaf tissue were collected from each treatment. The extraction and quantification methodology was described by Kolb et al. (2001), with minor modifications. Dry leaf tissue samples were placed in $250 \mathrm{~mL}$ Erlenmeyer flasks with $100 \mathrm{~mL}$ of $70 \%$ ethanol. The solution was heated to $70^{\circ} \mathrm{C}$ and stirred for $30 \mathrm{~min}$. After cooling, a $10 \mathrm{~mL}$ aliquot was filtered (quantitative filter paper and a $0.22 \mu$ m nylon syringe filter). $0.3 \mathrm{~mL}$ of the leaf tissue samples was used for each treatment, with $0.7 \mathrm{~mL}$ of HPLC grade acetonitrile. From this dilution, $20 \mu \mathrm{L}$ was injected for further analysis in a High Performance Liquid Chromatograph (Shimadzu CBM-10A) containing a Phenomenex Luna ${ }^{\circledR} 5 \mu \mathrm{m}$ NH2 $100 \AA$, $250 \times 4.6 \mathrm{~mm}$ column. The elution was at room temperature in the isocratic mode using a mixture of acetonitrile-distilled water (80:20, v/v) and a flow rate of $2 \mathrm{~mL} \mathrm{~min}^{-1}$. The detection was done with UV at $210 \mathrm{~nm}$ with sensitivity adjusted to 0.04 AUFS. Readings were taken in triplicate. The quantification of each metabolite was obtained by converting the area of the curve corresponding to retention time using a previously established calibration curve. The standard solution for obtaining the calibration curve was 1.0 $\mathrm{g} \mathrm{L}^{-1}$ stevioside and rebaudioside $\mathrm{A}$ in $\mathrm{MeOH}$ (Kolb et al., 2001). The conversion was expressed in $\mathrm{mg} \mathrm{g}^{-1}$ and corresponded to the percentage of each secondary metabolite.

The results were submitted to analysis of variance using Assistat software, version 7.7 beta (Silva and Azevedo, 2009). Initially, the treatment variances were evaluated for homogeneity with the Bartlett test. The variables whose variances were homogeneous were tested with the $\mathrm{F}$ test. If significant, the means were compared with the Tukey test at $5 \%$ probability.

\section{RESULTS AND DISCUSSION}

\section{Plant growth}

The means of the variables total dry weight yield, stem dry weight yield, leaf dry weight yield, number of secondary and tertiary branches, and length of the largest stem showed a linear effect as a function of nitrogen doses and are shown in figures 1 and 2 .

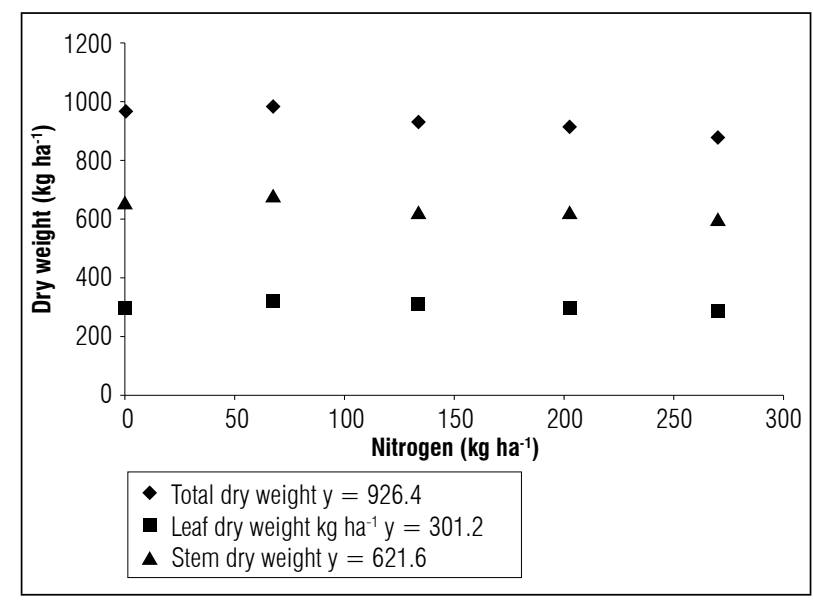

Figure 1. Total leaf and stem dry weight yields of the stevia genotype subjected to $\mathbf{N}$ doses.

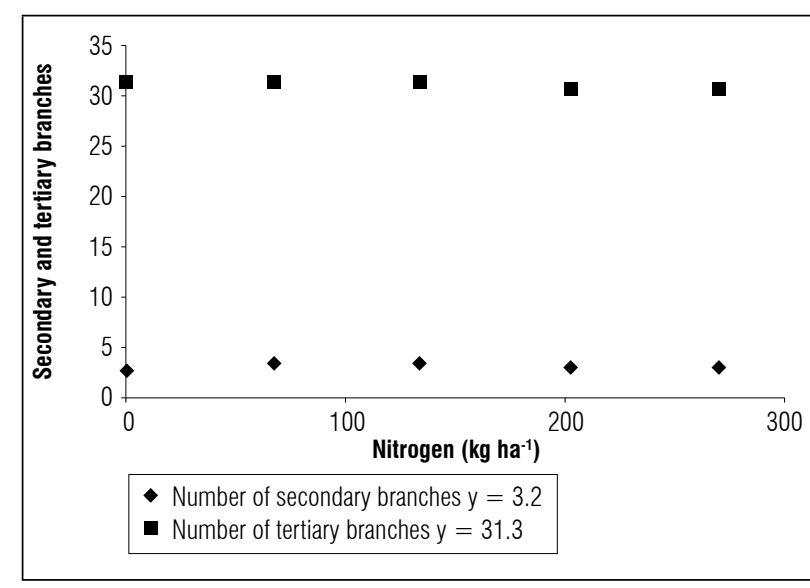

Figure 2. Number of secondary and tertiary branches of the stevia genotype subjected to $\mathbf{N}$ doses.

The nitrogen fertilization increased the leaf dry matter yield and growth variables such as leaf area index (Rashid et al., 2013; Francisco, 2015; Tavarini et al., 2015). These variables are directly associated with nitrogen metabolism and interfere in the synthesis of Ribulose-1,5-bisphosphate carboxylase/oxygenase 
(Rubisco). Thus, they affect the crop yield potential because of enzymatic synthesis of the photosynthetic apparatus (Tavarini et al., 2015) and are directly reflected in plant growth.

In stevia, leaf dry weight is the most relevant variable for the dry weight yield because stevioside and rebaudioside $\mathrm{A}$ are more abundant in this organ (Hsieh and Goodman, 2005; Jarma et al., 2010).

The lack of differences in leaf dry weight yield among the nitrogen doses (Fig. 1) can be explained by the interaction of external factors, such as photoperiod (directly interfering with the crop production cycle) and soil $\mathrm{pH}$ levels (directly affecting nutrient availability to plants (Yang et al., 2014). Another factor that must be taken into consideration is the nutritional needs of the stevia crop itself, as well as nitrogen uptake capacity (Duncan and Baligar, 1990).

There are studies with native Asteraceae from the Cerrado region of Brazil, especially Vernonia herbacea, that have shown that plants grown in greenhouses and treated with nutrient solution in sandy substrate increased the growth of shoot organs (Teixeira et al., 1997). On the other hand, Carvalho et al. (1998) found that $V$. herbacea fertilized with nitrogen in the field did not increase the shoot and root dry weight yields. According to the author, plants originating from conditions with low soil fertility and subjected to conditions of high fertility promoted by fertilizers can promote changes in the nutritional balance of $V$. herbacea. Thus, the result is reduced growth and gains in leaf, stem and root dry weight of said culture.

Nitrogen from soil organic matter may have met the needs of the stevia crop. For this reason, the different doses of nitrogen did not affect the variables related to dry weight yield (Fig. 1).

Stevia is a short-day plant and has a critical photoperiod of 12 to $13 \mathrm{~h}$ (Ceunen and Geuns, 2013a). Long days increase the growth period of stevia, directly affecting growth rates and dry weight yield (Ceunen and Geuns, 2013a).

Photoperiod is an important factor in the modulation of several genes in stevia, especially those involved in the transcription and synthesis of steviol glycoside (Yang et al., 2014). Short days promote entry into the reproductive phase of stevia (Ceunen and Geuns, 2013a, 2013b, 2013c).
Together with the nutritional changes promoted by nitrogen fertilization, a decreasing photoperiod may have contributed to the lack of differences among treatments.

The formation of secondary and tertiary branches is directly related to total dry weight yield. According to Pal et al. (2015), the growth of lateral branches in stevia is associated with the development of the root system. This author reported that more developed root systems synthesize larger amounts of cytokines, which are phytohormones responsible for stimulating lateral branch formation. Changes in the nutritional balance of stevia G8 and decreased photoperiods impair dry weight yield, so plants have reduced root system development and lower cytokine production (Carvalho et al., 1998). Thus, there were no differences between the treatments for the number of secondary and tertiary branches (Fig. 2).

The number of secondary and tertiary branches was represented by the mean as a function of nitrogen doses (Fig. 2).

The variables TLA, LAI, LAR, SLA and LWR did not vary with the nitrogen fertilization (Fig. 3 and 4).

Total leaf area of a crop represents the ability of a genotype to maintain leaf area for a longer period, enabling better performance of the photosynthetic apparatus.

The lack of differences in the TLA for the different doses of nitrogen can be explained by the $\mathrm{N}$ source. According to Carvalho et al. (1998), high doses of urea converted to $\mathrm{NH}_{4}$ promote disturbances in total dry weight yield.

In addition to nutritional disorders, the photoperiod may have also had negative effects on the growth variables. The plants, regardless of the photoperiod, showed increased growth and leaf dry weight yield in the long days. This was due to increased leaf area and photosynthetic production (Castro et al., 2003).

According to Watson (1947), the leaf area index is the unilateral total area of leaf tissue per unit of soil surface area. There were no differences between the treatments for this variable (Fig. 4). Similarly, the TLA was not influenced by nitrogen fertilization and decreasing photoperiods (Fig. 3). The results of this study are consistent with those found by Francisco (2015) in the greater Curitiba region (Brazil). 


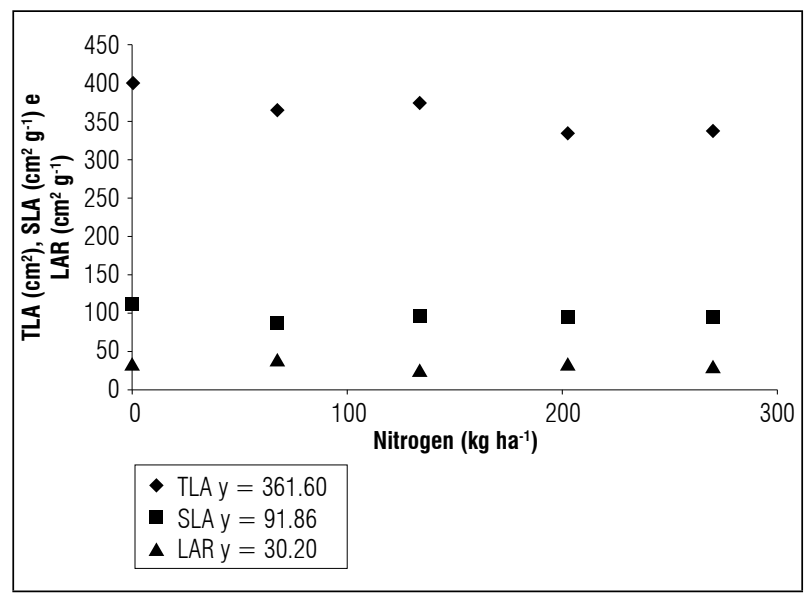

Figure 3. Total leaf area (TLA), specific leaf area (SLA) and leaf area ratio (LAR) of stevia subjected to nitrogen doses.

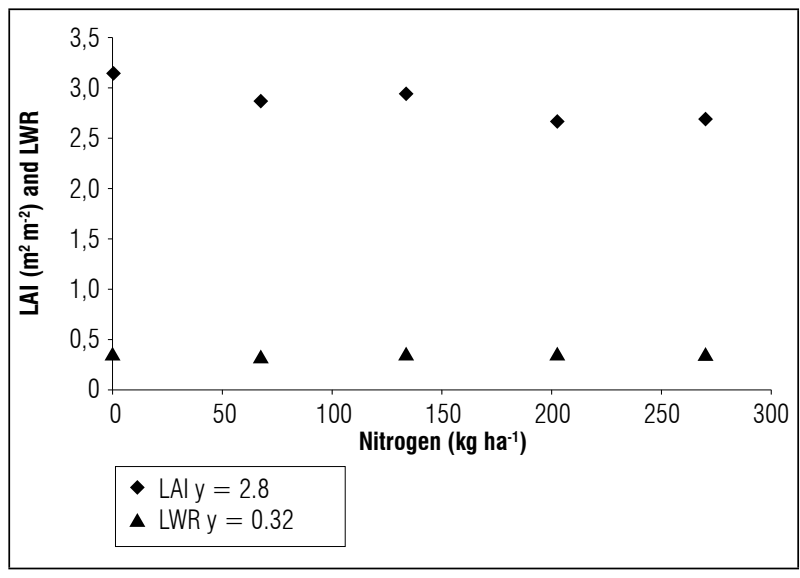

Figure 4. Leaf area index (LAI) and leaf weight ratio (LWR) of the stevia subjected to nitrogen doses.

Although no differences were found between the doses of $\mathrm{N}$, the LAI decreased as the doses increased. This behavior can be explained by the nutritional dysfunctions generated by nitrogen fertilization in different doses that directly affects the TLA variable. According to Magalhães (1986), the leaf area ratio expresses the area used for photosynthesis, i.e., leaf area that is used to produce $1 \mathrm{~g}$ of dry weight. This variable was also not affected by the $\mathrm{N}$ fertilization (Fig. 3).

Since the leaf area ratio is dependent on total dry weight yield and total leaf area, this variable showed a similar behavior to the other growth variables (Fig. 3).

According to Benincasa (2003), specific leaf area is the ratio between leaf area and leaf dry weight and provides an indication of the leaf area required for the synthesis of $1 \mathrm{~g}$ leaf dry weight. Since the accumulation of stevioside and rebaudioside A occurs mostly in the leaves, SLA was significantly relevant in our assessments.

Similar to the TLA and LAR, the SLA did not show differences among the $\mathrm{N}$ doses (Fig. 3 ). This can be attributed to the decreasing photoperiod (Ceunen and Geuns, 2013c).

The photoperiod influences the SLA of guaco (Castro et al., 2003). According to this author, photoperiods of 16 to $20 \mathrm{~h}$ reduce the SLA in guaco, as compared to photoperiods of 8 to $12 \mathrm{~h}$. This is because guaco leaves subjected to longer photoperiods produce thicker leaves, which was not the case in our study (Fig. 3).

When evaluating stevia genotypes in the climate and soil conditions of the greater Curitiba region, Francisco (2015) found divergent results between two cultivation conditions: one with increasing photoperiods and another with decreasing photoperiods. This author found higher dry weight yields under conditions of increasing photoperiods. The LDW values were $75.14 \%$ lower in the decreasing photoperiod than in the increasing photoperiod.

When assessing growth rates (SLA specifically), Francisco (2015) found values for stevia G8 (same used in this study) of $136.20 \mathrm{~cm}^{2} \mathrm{~g}^{-1}$, which is $43.5 \%$ higher than the average value of $94.88 \mathrm{~cm}^{2} \mathrm{~g}^{-1}$ found in our study. This shows that decreasing photoperiods negatively influence growth rates.

The leaf weight ratio is an important variable to determine the dry weight yield. It is a physiological parameter that expresses the leaf dry weight fraction, which is not transferred to the rest of the plant. Francisco (2015) found LWR values for the stevia G8 grown in the metropolitan region of Curitiba equal to $0.34 \mathrm{~g} \mathrm{~g}^{-1}$. Our results ranged from 0.31 to $0.33 \mathrm{~g}$ $\mathrm{g}^{-1}$ (Fig. 4).

The relationship between TLA, LAI, SLA, LAR and LWR as a function of $N$ doses can be represented by the means of each variable (Fig. 3 and 4).

\section{Stevioside and rebaudioside A yield}

The stevioside and rebaudioside A content, stevioside and rebaudioside A yield, and rebaudioside A: stevioside ratio did not vary with the nitrogen fertilization (Fig. 5). 


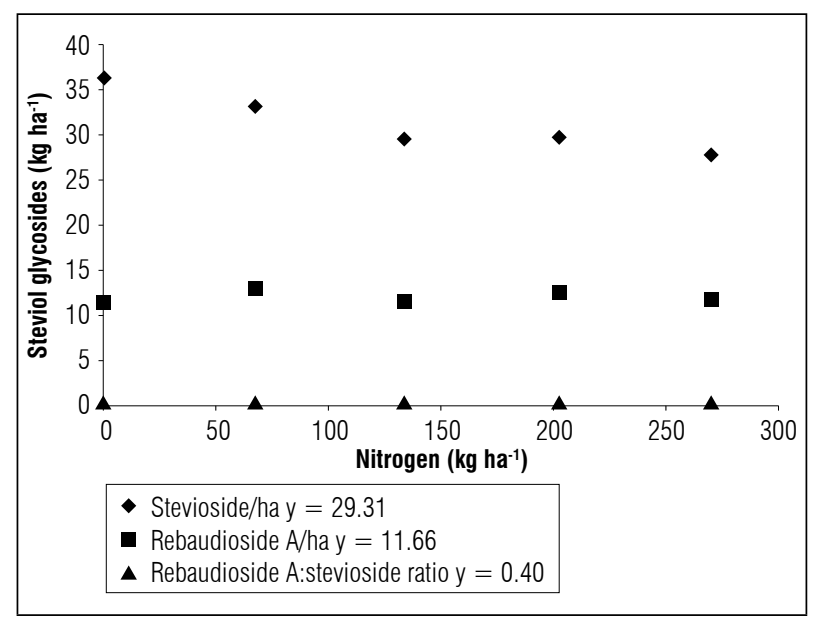

Figure 5. Stevioside and rebaudioside $A$ yield and rebaudioside A:stevioside ratio of stevia genotype subjected to nitrogen doses.

The relationship between the stevioside and rebaudioside A yield with $\mathrm{N}$ fertilization can be represented by the mean of the variables (Fig. 5).

Nitrogen $(N)$ is an essential element for the growth of stevia (Akbari et al., 2018) and, according to Sun et al. (2020), is important for the synthesis of steviol glycosides (SG).

The synthesis of secondary metabolites is influenced by several factors, such as competition for nutrients with primary metabolism. In situations with abiotic stress, plants prioritize the maintenance of primary metabolism and the protection of photosynthetic apparatus (Taiz and Zeiger, 2013).

In a study by Francisco (2015), there was high correlation between the leaf dry weight yield and stevioside content. In this study, there was no increase in the stevioside content (Fig. 5). There was also no increase in the stevioside yield.

Sun et al. (2019) reported that steviol glycoside synthesis is dependent on an adequate fertilization regime. However, the influence of $\mathrm{N}$ fertilization on secondary metabolite synthesis in stevia is not welldefined. The authors reported that $\mathrm{N}$ doses did not significantly interfere with the levels of steviol glycosides. In fact, there were reduced concentrations in leaves because of the dilution effect.

Akbari et al. (2018) demonstrated (in vitro) that different sources and doses of $\mathrm{N}$ affect the gene expression responsible for enzymatic synthesis (UGT74G1 and UGT76G1), undergoing increases; however, in the present study, the increase in the expression reported by these authors were not observed according to the concentration of SG (Fig. 5).

Failure to observe the effect of nitrogen fertilization on stevioside content and yield is a direct reflection of the lack of differences in dry weight yield and growth rates (Fig. 2, 3, 4).

The rebaudioside A content and yield followed the same trend as stevioside, i.e., there were no differences among the treatments. In evaluating the stevioside and rebaudioside A content and yield of stevia genotypes under decreasing photoperiods, Francisco (2015) found a $27.9 \%$ reduction in the stevioside content and $36.6 \%$ in the rebaudioside A content although Yoneda et al. (2017) did not observe the influence of the photoperiod on gene modulation, especially for the UGT85C2 gene. According to Francisco (2015), this behavior may be associated with less favorable environmental conditions, such as decreasing photoperiods.

In this study, there was a lower LDW yield because of the shorter growth period of stevia G8, caused by the unfavorable environmental conditions mentioned by Francisco (2015). According to Ceunen and Geuns (2013c), decreasing photoperiods provide a lower leaf dry weight yield and, consequently, lower stevioside and rebaudioside A yield (Fig. 5).

In addition to the influences generated by the declining photoperiods, different soil classes, with different $\mathrm{pH}$ levels, can interfere with stevia productivity (Zaman et al., 2015). The environmental and soil conditions generate evolutionary compatibility of the crop with the type of soil and the availability of nutrients and water (Zaman et al., 2015). Soils with a high pH, calcareous soils and soils corrected with high doses of limestone hinder the development of stevia cultures, harming the accumulation of biomass (Zaman et al., 2015). The liming and fertilization manual for the states of Rio Grande do Sul and Santa Catarina recommends the correction of soil intended for the cultivation of stevia with the addition of limestone to reach $\mathrm{pH}$ 6.0. This $\mathrm{pH}$, according to Zaman et al. (2015), is not suitable for this culture. According to the same author, a stevia cultivation shows better productive performances in soils with an acidic $\mathrm{pH}$, below 5.5. Thus, the levels of diterpenic glycosides, as well as the accumulation of biomass, may have 
suffered negative influences both by the declining photoperiod, as well as by the inadequate $\mathrm{pH}$ range of the soil in the experimental area, which was 5.2 before liming.

The rebaudioside A:stevioside ratio is a determining factor in evaluating new stevia genotypes. According to Mota et al. (2011), the ideal rebaudioside A:stevioside ratio for industrial use is 1 . There were no differences in the rebaudioside A:stevioside ratio among the $\mathrm{N}$ doses.

\section{CONCLUSION}

The different doses of nitrogen fertilization did not increase the dry weight yield of stevia grown under decreasing photoperiod conditions in the Alto Vale do Itajaí region (SC).

The nitrogen fertilization did not increase the contents and yields of diterpene glycosides.

None of the nitrogen doses applied in our study had a suitable Rebaudioside A:stevioside ratio for industrial uses (i.e., close to 1 ).

Conflict of interests: The manuscript was prepared and reviewed with the participation of the authors, who declare that there exists no conflict of interest that puts at risk the validity of the presented results.

\section{BIBLIOGRAPHIC REFERENCES}

Aladakatti, Y.R., Y.B. Palled, M.B. Chetti, S.I. Halikattim, S.C. Alagundagi, P.L. Patil, V.C. Patil, and A.D. Janawade. 2012. Effect of nitrogen, phosphorus and potassium levels on growth and yield of stevia (Stevia rebaudiana Bertoni). Karnataka J. Agric. Sci. 25(1), 25-29.

Akbari, F., A. Arminian, D. Kahrizi, A. Fazeli, and M. Ghaheri. 2018. Effect of nitrogen sources on gene expression os Stevia rebaudiana (Bertoni) under in vitro conditions. Cell. Mol. Biol. 64(2), 11-16. Doi: 10.14715/ $\mathrm{cmb} / 2018.64 .2 .3$

Benincasa, M.M.P. 2003. Análise de crescimento de plantas: noções básicas. FUNEP, Jaboticabal, Brazil.

Cantarella, H. 2007. Nitrogênio. pp. 375-470. In: Novais, R.F., V.H. Alvarez V., N.F. Barros, R.L.F. Fontes, R.B. Cantarutti, and J.C.L. Neves (eds.). Fertilidade do solo. Sociedade Brasileira de Ciência do Solo, Vicosa, Brazil.

Carvalho, M.A.M., M.M. Pinto, and R.C.L. Figueiredo-Ribeiro. 1998. Inulin production by Vernonia hebacea as influenced by mineral fertilization and time of harvest. Rev. Bras. Bot. 21, 275-280. Doi: 10.1590/ S0100-84041998000300006

Carvalho, M.A.M. and L.B.P. Zaidan. 1995. Obtenção de plantas de Stevia rebaudiana através de estacas. Pesq. Agropec. Bras. 30(2), 201-206.

Castro, E.M., J.E.B.P. Pinto, A.A. Alvarenga, E.D.C.L. Júnior, S.K.V. Bertolucci, J.L.D.S. Filho, and C.V. Vieira. 2003. Crescimento e anatomia foliar de plantas jovens de Mikania glomerata Sprengel (Guaco) submetidas a diferentes fotoperíodos. Cienc. Agrotec. 27(6), 12931300. Doi: 10.1590/S1413-70542003000600013

Ceunen, S. and J.M.C. Geuns. 2013a. Spatio-temporal variation of the diterpene steviol in Stevia rebaudiana grown under different photoperiods. Phytochemistry 89, 32-38. Doi: 10.1016/j.phytochem.2013.01.007

Ceunen, S. and J.M.C. Geuns. 2013b. Glucose, sucrose, and steviol glycoside accumulation in Stevia rebaudiana grown under different photoperiods. Biol. Plant. 57, 390-394. Doi: 10.1007/s10535-012-0289-6

Ceunen, S. and J.M.C. Geuns. 2013c. Influence of photoperiodism on the spatiotemporal accumulation of steviol glycosides in Stevia rebaudiana (Bertoni). Plant Sci. 198, 72-82. Doi: 10.1016/j.plantsci.2012.10.003

Cunha, J.L.X.L., P.G.M.L. Naascimento, H.C. Mesquita, M.G.O. Silva, J.L.D. Dombroski, and I.N. Silva. 2010. Comparação de métodos de área foliar em Chrysobalanus icaco L. ACSA -Agropec. Cient. Semi-Árido 6(3), 22-27.

Duncan, R.R. and V.C. Baligar. 1990. Genetics, breeding, and physiological mechanisms of nutrient uptake and use efficiency: an overview. pp. 3-35. In: Duncan, V.C. and R.R. Baligar (eds.). Crops as enhances of nutrient use. Academic Press, New York, NY. Doi: 10.1016/ B978-0-12-077125-7.50005-0

Embrapa. 2018. Sistema brasileiro de classificação de solos. $2^{\text {nd }}$ ed. Rio de Janeiro, Brazil.

Espita, M., R. Montoya, and L. Atencio. 2009. Rendimiento de Stevia rebaudiana Bert. bajo tres arreglos poblacionales en el Sinú Medio. Rev. UDCA Actual. Divulg. Cient. 12(1), 151-161. Doi: 10.31910/rudca.v12. n1.2009.651

Francisco, F. 2015. Acúmulo de biomassa, produção de esteviosídeo e rebaudiosídeo A e tolerância à geada e ao acamamento de acessos de Stevia rebaudiana bert. MSc thesis. Universidade Federal do Paraná, Parana, Brazil.

Gobbo-Neto, L. and N.P. Lopes. 2007. Medicinal plants: factors of influence on the content of secondary metabolites. Quím. Nova 30(2), 374-381. Doi: 10.1590/ S0100-40422007000200026

Hsieh, M.-H. and H.M. Goodman. 2005. The Arabidopsis IspH homolog is involved in the plastid nonmevalonate pathway of isoprenoid biosynthesis. Plant Physiol. 138(2), 641-653. Doi: 10.1104/pp.104.058735 
Jarma, A., T. Rengifo, and H. Araméndez-Tatis. 2006. Fisiología de estevia (Stevia rebaudiana) en función de la radiación en el Caribe colombiano. II. Análisis de crecimiento. Agron. Colomb. 24(1), 38-47.

Kolb, N., J.L. Herrera, D.J. Ferreyra, and R.F. Uliana. 2001. Analysis of sweet diterpeno glycosides from Stevia rebaudiana: improved HPLC method. J. Agric. Food Chem. 49 (10), 4538-4541. Doi: 10.1021/jf010475p

Lima Filho, O.F., A.C.C. Valois, and Z.M. Lucas. 2004. Sistema de produção 5: Estévia. Embrapa Agropecuaria Oeste; Steviafarma Industrial, Dourados, Brazil.

Magalhães, A.C.N. 1986. Análise quantitativa do crescimento. pp. 331-350. In: Ferri, M.G. (ed.). Fisiologia vegetal. $2^{\text {nd }}$ ed. rev. e atual. EPU/EDUSP, São Paulo, Brazil.

Mota, T.R., A.S. Dacome, and S.C. Costa. 2011. Seleção de clones de elite de Stevia rebaudiana (Bert.) Bertoni com ênfase no teor do rebaudiosídeo $\mathrm{A}$ e a atividade antioxidante. Anais eletrônicos. In: Proc. VII EPCC - Encontro Internacional de Produção Científica. CESUMAR, Maringá, Parana, Brazil.

Jarma Orozco, A., M. Espitia Camacho, and G. Fischer. 2010. Síntesis de esteviosidos en estévia (Stevia rebaudiana Bert.). Acta Biol. Colomb. 15(1), 289-294.

Pal, P.K., M. Mahajan, R. Prasad, V. Pathania, N. Singh, and P.S. Ahuja. 2015. Harvesting regimes to optimize yield and quality in annual and perennial Stevia rebaudiana under sub-temperate conditions. Ind. Crops Prod. 65, 556-564. Doi: 10.1016/j.indcrop.2014.09.060

Rashid, Z., M. Rashid, S. Inamullah, S. Rasool, and F.A. Bahar. 2013. Effect of different levels of farmyard manure and nitrogen on the yield and nitrogen uptake by stevia (Stevia rebaudiana Bertoni). Afr. J. Agric. Res. 8(29), 3941-3945.

SBCS, Sociedade Brasileira de Ciência do Solo. 2016. Manual de calagem e adubação para os estados do Rio Grande do Sul e Santa Catarina. 11 ${ }^{\text {th }}$ ed. Comissão de química e fertilidade do solo, Porto Alegre, Brazil.

Silva, F.A.S. and C.A.V. Azevedo. 2009. Principal components analysis in the software assistat-statistical attendance. Id. 711P0409e. In: Proc. $7^{\text {th }}$ World Congress on Computers in Agriculture. Am. Soc. Agric. Biol. Eng., Reno, NV.

Sun, Y., M. Hou, L.A.J. Mur, Y. Yang, T. Zhang, X. Xu, S. Huang, and H. Tong. 2019. Nitrogen drives plant growth to the detriment of leaf sugar and steviol glycosides metabolisms in stevia (Stevia rebaudiana
Bertoni). Plant Physiol. Biochem. 141, 240-249. Doi: 10.1016/j.plaphy.2019.06.008

Sun, Y., Y. Yang, M. Hou, X. Huang, T. Zhang, S. Huang, X. Xu, and H. Yuan. 2020. Optimized nitrogen topdressing strategies enhance steviol glycoside productivity in stevia (Stevia rebaudiana Bertoni) plants. J. Soil Sci. Plant Nutr. 20, 1133-1143. Doi: 10.1007/ s42729-020-00199-w

Taiz, L. and E. Zeiger. 2013. Fisiologia vegetal. $5^{\text {th }}$ ed. Artemed, Porto Alegre, Brazil.

Tavarini, S., C. Sgherri, A.M. Ranieri, and L.G. Angelini. 2015. Effect of nitrogen fertilization and harvest time on steviol glycosides, flavonoid composition and antioxidant properties in Stevia rebaudiana Bertoni. J. Agr. Food Chem. 63(31), 7041-7050. Doi: 10.1021/acs. jafc. 5 b02147

Teixeira, P.G., M.A.M. Carvalho, L.B.P. Zaidan, and A.L. Klein. 1997. Effect of mineral nutrients on growth and fructan contents in plants of Vernonia herbacea. Rev. Bras. Fisiol. Veg. 9(2), 89-96.

Yadav, A.K., S. Singh, D. Dhyani, and P.S. Ahuaja. 2011 A review on the improvement of stevia [Stevia rebaudiana Bertoni]. Can. J. Plant Sci. 91, 1-27. Doi: 10.4141/ cjps10086

Yang, Y., S. Huang, Y. Han, H. Yuan, C. Gu, and Z. Wang. 2014. Environmental cues induce changes of steviol glycosides contents and transcription of corresponding biosynthetic genes in Stevia rebaudiana. Plant Physiol. Biochem. 86, 174-180. Doi: 10.1016/j. plaphy.2014.12.004

Yoneda, Y., H. Shimizu, H. Nakashima, J. Miyasaka, and K. Ohdoi. 2017. Effects of light intensity and photoperiod on improving steviol glycosides content in Stevia rebaudiana (Bertoni) Bertoni while conserving light energy consumption. J. Appl. Res. Med. Aroma. 7, 6473. Doi: 10.1016/j.jarmap.2017.06.001

Watson, D.J. 1947. Comparative physiological studies on growth of field crops. I. Variation in net assimilation rate and leaf area between species and varieties, and within and between years. Ann. Bot. 11(1), 41-76. Doi: 10.1093/oxfordjournals.aob.a083148

Zaman, M.M., M.A.H. Chowdhury, and T. Chowdhury. 2015. Growth parameters and leaf biomass yield of stevia (Stevia rebaudiana Bertoni) as influenced by different soil types of Bangladesh. J. Bangladesh Agril. Univ. 13(1), 31-37. 